\title{
Pengetahuan Lokal Tanaman Pangan dan Pemanfaatannya pada Masyarakat Suku Using Kabupaten Banyuwangi
}

\author{
N. Nurchayati ${ }^{1 *}$, Fuad Ardiyansyah ${ }^{1)}$ \\ ${ }^{1)}$ Program Studi Biologi, Fakultas Matematika dan Ilmu Pengetahuan Alam, Universitas PGRI Banyuwangi, Jl. Ikan \\ Tongkol 01, Banyuwangi, Jawa Timur, Indonesia \\ ${ }^{*}$ Alamat korespondensi: nnurchayati99@gmail.com
}

\begin{abstract}
ABSTRAK
Pangan adalah kebutuhan utama manusia dan terus meningkat seiring perkembangan jumlah penduduk. Kebutuhan pangan dapat dipenuhi dari sumber daya alam yang ada, terutama dari golongan tumbuhan. Etnobotani adalah ilmu yang mempelajari interaksi antara manusia dengan tumbuhan salah satunya dalam memenuhi kebutuhan pangan. Pola pemanfaatan tumbuhan oleh suatu masyarakat sangat berkaitan dengan kebudayaan mereka. Sehingga kebudayaan suatu daerah dapat menentukan jenis pangan, cara pengolahan dan penyajiannya. Pemanfaatan tanaman adalah sesuatu yang kental bagi suku Using terutama dalam memenuhi kebutuhan pangan. Dokumentasi pemanfaatan tanaman pangan oleh suku Using belum banyak dilakukan, sehingga peneliti merasa perlu untuk melakukan penelitian tentang pengetahuan lokal terhadap tanaman pangan dan pemanfaatannya pada masyarakat suku Using Kabupaten Banyuwangi. Tujuan penelitian ini adalah untuk mengetahui pengetahuan lokal masyarakat suku Using terhadap tanaman pangan serta cara pemanfaatannya dalam kehidupan sehari-hari. Lokasi penelitian dilakukan di lima kecamatan meliputi Glagah, Giri, Kabat, Singojuruh dan Rogojampi. Metode penelitian adalah survei dengan pegambilan sampel menggunakan teknik purposive random sampling. Pengumpulan data pemanfaatan tanaman dengan wawancara terstruktur dan semi-terstruktur. Hasil penelitian diperoleh 40 spesies tanaman yang dimanfaatkan sebagai bahan pangan dan tergabung dalam 25 famili. Tanaman pangan dikategorikan dalam bahan pangan utama, bahan pangan tambahan dan bahan minuman beraroma. Bahan pangan tambahan meliputi umbi-umbian, sayur-mayur, buahbuahan, biji-bijian, kacang-kacangan, bumbu dan aroma masakan. Habitus tanaman yang banyak dimanfaatkan adalah perdu, semak dan terna. Tanaman pangan banyak diperoleh dari hasil budi daya, dengan organ buah lebih banyak dimanfaatkan. Cara pengolahan yang paling sering dilakukan adalah dengan cara dimasak.
\end{abstract}

Kata kunci: etnobotani, tanaman pangan, suku Using, Banyuwangi

\section{Local Knowledge of Food Crops and Its Utilization in Using Tribe of Banyuwangi Regency}

N. Nurchayati ${ }^{1) *}$, Fuad Ardiyansyah ${ }^{1)}$

${ }^{1)}$ Study Program of Biology, Faculty of Mathematics and Natural Sciences, University of PGRI Banyuwangi, JI. Ikan

Tongkol 01, Banyuwangi, East Java, Indonesia

${ }^{*}$ Email: nnurchayati99@gmail.com

\section{ABSTRACT}

Food is the main human needs and continue to increase as the population grows. Food can be met from existing natural resources, one of which is plants. Ethnobotany is the study of the interaction between humans and plants in food needs. The pattern of utilization of plants in a society is closely related with their culture. Therefore, the culture of a region will determine the type of foods, the way food is proceesed and presented. The utilization of plants is important for the Using tribe especially in fulfilling food needs. The documentation of the use of food crops by the Using tribe has not been to conduct research on local knowledge of food crops and their use in Using communities of Banyuwangi Regency. The purpose of this study was to determine the local knowledge of Using tribal communities on food crops and how to utilize them in daily life. The location of this were conducted in five sub-districts including Glagah, Giri, Kabat, Singojuruh and Rogojampi. The research method used was a survey with sample collection using purposive random sampling technique. Data crop utilization with structured and semistuctured interviews. This study obtained 40 species of plants that were used as food ingredients, and these species was part of 25 families. Food crops were categorized the main dishes, side dishes and flavoring 
beverages. The side dishes include tubers, vegetables, fruits, grains, nuts, spices and flavoring agents. The plant habitus that were widely used were shrubs, bushes and shades. The food crops were mostly obtained from cultivation, with fruits were the most utilized. The most common method in processing the food crops is cooking.

Keywords: ethnobotany, plant, food crops, Using tribe, Banyuwangi

\section{PENDAHULUAN}

Kebutuhan pangan adalah kebutuhan yang paling utama bagi manusia. Kebutuhan pangan terus meningkat seiring peningkatan jumlah penduduk. Data dari Badan Pusat Statistik (BPS) menunjukkan bahwa untuk memenuhi kebutuhan pangan di tahun 2011, Indonesia telah melakukan impor pangan senilai 11,33 ton. Ini sangat bertolak belakang dengan kondisi Indonesia yang kaya sumber daya alam. Pemenuhan kebutuhan pangan seharusnya dapat dilakukan dengan memanfaatkan sumber daya alam berpotensi di sekitar kita. Masyarakat sering kali memanfaatkan tanaman tumbuhan yang ada di alam untuk memenuhi kebutuhan pangan [1].

Etnobotani merupakan suatu kajian mengenai interaksi antara masyarakat lokal suatu daerah dengan lingkungan alam dalam pemanfaatan tumbuhan untuk memenuhi kebutuhan hidupnya [2]. Pola pemanfaatan tumbuhan suatu masyarakat sangat berkaitan dengan kebudayaan mereka. Sehingga kebudayaan suatu daerah tertentu akan menentukan jenis pangan, cara pengolahan dan penyajiannya [3].

Suku Using merupakan salah satu suku yang mendiami wilayah Banyuwangi. Suku ini sangat kental dengan adat-istiadatnya. Suku Using mendiami wilayah tertentu di Banyuwangi, khususnya daerah Glagah, Giri, Kabat, Rogojampi dan Singojuruh. Pemanfaatan tanaman masih menjadi kebiasaan utama bagi suku Using, terutama dalam hal memenuhi kebutuhan pangan. Suku Using masih memiliki banyak kearifan lokal dalam pemanfaatan tanaman. Tanaman pangan yang diolah oleh masyarakat suku Using tidak hanya sebagai bahan makanan pokok, tetapi juga untuk memenuhi kebutuhan camilan, kue, bahan pangan tambahan, sayur-mayur, buahbuahan baik utuk pangan sehari-hari maupun untuk ritual [4].

Dokumentasi terkait pemanfaatan tanaman pangan oleh suku Using belum banyak dilakukan. Sehingga penelitian tentang pengetahuan lokal terhadap tanaman pangan dan pemanfaatannya pada masyarakat suku Using Kabupaten Banyuwangi perlu untuk dilakukan.

Tujuan dari penelitian ini adalah untuk mengkaji pengetahuan lokal masyarakat suku Using terhadap tanaman pangan dan cara memanfaatkannya dalam kehidupan seharihari. Harapannya informasi yang diperoleh dari penelitian ini dapat digunakan untuk memperkuat data bioekologi serta menjadi dasar dalam pengelolaan kawasan berbasis kesejahteraan masyarakat dan kelestarian lingkungan hidup.

\section{METODE PENELITIAN}

Tempat penelitian berada pada lima kecamatan yang meliputi: Kecamatan Glagah (Kemiren, glagah, Taman Suruh, Bakungan, Mandaluko, Olehsari, Kenjo, Dukuh Kopen Kidul); Kecamatan Giri (Cungking Mojopanggung, Boyolangu); Kecamatan Kabat (Macan Putih, Kejoyo); Kecamatan Rogojampi (Aliyan); dan Kecamatan Singojuruh (Alas Malang) (Gambar 1).

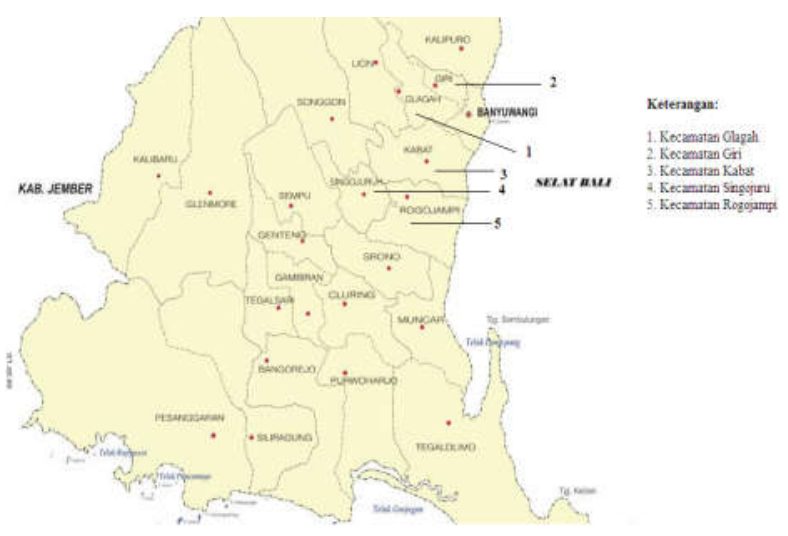

Gambar 1. Peta lokasi penelitian yang meliputi Kecamatan Glagah, Giri, Kabat, Singojuruh dan Rogojampi Banyuwangi [5]

Metode yang digunakan pada penelitian ini adalah metode survei dengan pengambilan sampel menggunakan teknik purposive random sampling. Pengumpulan data pemanfaatan tanaman dilakukan dengan wawancara baik 
terstruktur maupun semi-terstruktur menggunakan kuisioner dan pengamatan langsung. Jumlah responden dalam penelitian ini adalah 390 orang yang merupakan perwakilan dari masing-masing desa. Responden meliputi ibu rumah tangga, penjual makanan dan tokoh adat.

Identifikasi dilakukan pada tanaman yang dimanfaatkan sebagai bahan pangan oleh masyarakat suku Using Banyuwangi. Identifikasi yang dilakukan meliputi pencarian nama ilmiah dan nama famili dengan menggunakan buku Backer and Bring (1963) serta Gembong Tjotrosoepomo (1993). Data tanaman pangan dicatat nama lokalnya dan nama ilmiahnya, kemudian dilakukan pencandraan.

Perkiraan nilai manfaat dari spesies tanaman sebagai bahan pangan dilakukan dengan menggunakan rumus 1 [6].

$$
U V=\frac{\Sigma u}{n}
$$

Keterangan :

$U V$ : Nilai kegunaan atau Use Value

$\sum U$ : Jumlah informan yang mengetahui atau menggunakan spesies tumbuhan yang dimaksud

$n \quad:$ Jumlah informan seluruhnya

\section{HASIL DAN PEMBAHASAN}

Tanaman pangan di Indonesia dikelompokkan menjadi tiga; yaitu komoditas utama, misalnya padi (Oryza sativa), kedelai (Glycine max), kacang tanah (Arachis hypogaea), jagung (Zea mays); komoditas potensial, misalnya sorgum (Andropogon sorgum), sagu (Metroxylon sp.); dan komoditas introduksi, misalnya ganyong (Canna edulis), jawawut (Panicum viridae) [7].

Potensi tanaman pangan Suku Using Kabupaten Banyuwangi. Berdasarkan hasil wawancara dengan responden diperoleh 40 spesies tanaman yang dimanfaatkan sebagai bahan pangan dan tergabung dalam 25 famili (Tabel 1).
Tabel 1. Ragam tanaman bermanfaat sebagai tanaman pangan pada Suku Using Kabupaten Banyuwangi

\begin{tabular}{|c|c|c|c|c|}
\hline \multirow{2}{*}{ No } & \multicolumn{2}{|c|}{ Jenis Tanaman } & \multirow{2}{*}{ Famili } & \multirow{2}{*}{$\begin{array}{c}\text { Nilai } \\
\text { Kegunaan }\end{array}$} \\
\hline & Lokal & Ilmiah & & \\
\hline 1 & Semanggi & $\begin{array}{l}\text { Marcilea } \\
\text { crenata L }\end{array}$ & Marsileaceae & 0,0026 \\
\hline 2 & Kelapa & $\begin{array}{l}\text { Cocos } \\
\text { nucifera } \mathrm{L}\end{array}$ & Arecaceae & 0,0051 \\
\hline 3 & Beluntas & $\begin{array}{l}\text { Pluchea } \\
\text { indica } \mathrm{L}\end{array}$ & Asteraceae & 0,0026 \\
\hline 4 & Pepaya & $\begin{array}{l}\text { Carica } \\
\text { papaya } \mathrm{L}\end{array}$ & Caricaceae & 0,0051 \\
\hline 5 & Kelor & $\begin{array}{l}\text { Moringa } \\
\text { oleifera } \mathrm{L} \text {. }\end{array}$ & Moringaceae & 0,0077 \\
\hline 6 & Sabrang & $\begin{array}{l}\text { Ipomoee } \\
\text { batatas } \mathrm{L}\end{array}$ & $\begin{array}{l}\text { Convolvulace } \\
\text { ae }\end{array}$ & 0,0051 \\
\hline 7 & Kangkung & $\begin{array}{l}\text { Ipomoee } \\
\text { aquatica } \mathrm{L}\end{array}$ & $\begin{array}{l}\text { Convolvulace } \\
\text { ae }\end{array}$ & 0,0051 \\
\hline 8 & Kecipir & $\begin{array}{l}\text { Psopocarpus } \\
\text { tetragonolobu } \\
s \mathrm{~L} \text {. }\end{array}$ & Fabaceae & 0,0051 \\
\hline 9 & Asam Jawa & $\begin{array}{l}\text { Tamarindus } \\
\text { indica } \mathrm{L} .\end{array}$ & Fabaceae & 0,0051 \\
\hline 10 & $\begin{array}{l}\text { Belimbing } \\
\text { wuluh }\end{array}$ & $\begin{array}{l}\text { Averrhoa } \\
\text { bilimbi L }\end{array}$ & Oxalidaceae & 0,0051 \\
\hline 11 & Alpukat & $\begin{array}{l}\text { Perseae } \\
\text { americana } \\
\text { Mill }\end{array}$ & Lauraceae & 0,0026 \\
\hline 12 & $\begin{array}{l}\text { Bawang } \\
\text { merah }\end{array}$ & Allium cepa $\mathrm{L}$ & Liliaceae & 0,0051 \\
\hline 13 & $\begin{array}{l}\text { Bawang } \\
\text { putih }\end{array}$ & $\begin{array}{l}\text { Allium } \\
\text { sativum L. }\end{array}$ & Liliaceae & 0,0051 \\
\hline 14 & $\begin{array}{l}\text { Sirsak } \\
\text { /muris }\end{array}$ & $\begin{array}{l}\text { Annona } \\
\text { muricata L. }\end{array}$ & Annonaceae & 0,0051 \\
\hline 15 & $\begin{array}{l}\text { Ketela } \\
\text { pohon } \\
\text { /sawi }\end{array}$ & $\begin{array}{l}\text { Manihot } \\
\text { esculenta } \mathrm{L}\end{array}$ & $\begin{array}{l}\text { Euphorbiacea } \\
\text { e }\end{array}$ & 0,0051 \\
\hline 16 & Salam & $\begin{array}{l}\text { Syzygium } \\
\text { polyanthum } \\
\text { L. }\end{array}$ & Myrtaceae & 0,0026 \\
\hline 17 & $\begin{array}{l}\text { Pandan } \\
\text { betawi /suji }\end{array}$ & $\begin{array}{l}\text { Dracaena } \\
\text { angustifolia } \\
\text { L. }\end{array}$ & Ruscaceae & 0,0051 \\
\hline 18 & $\begin{array}{l}\text { Pandan } \\
\text { wangi }\end{array}$ & $\begin{array}{l}\text { Pandanus } \\
\text { amaryllfolius } \\
\text { L. }\end{array}$ & Pandanaceae & 0,0026 \\
\hline 19 & Serai & $\begin{array}{l}\text { Cymbopogon } \\
\text { citratus L }\end{array}$ & Poaceae & 0,0051 \\
\hline 20 & Padi/pari & $\begin{array}{l}\text { Oryza sativa } \\
\mathrm{L}\end{array}$ & Poaceae & 0,0051 \\
\hline 21 & Ketan & $\begin{array}{l}\text { Oryza } \\
\text { glutinosa L. }\end{array}$ & Poaceae & 0,0051 \\
\hline 22 & Bambu & Bambusa sp. & Poaceae & 0,0026 \\
\hline 24 & Nangka & $\begin{array}{l}\text { Arthocarpus } \\
\text { heterophyllus } \\
\text { L. }\end{array}$ & Moraceae & 0,0026 \\
\hline 25 & Jeruk nipis & $\begin{array}{l}\text { Citrus } \\
\text { aurantifolia } \mathrm{L}\end{array}$ & Rutaceae & 0,0051 \\
\hline 26 & Mangga & $\begin{array}{l}\text { Mangifera } \\
\text { indica } \mathrm{L}\end{array}$ & $\begin{array}{l}\text { Anacardiacea } \\
\text { e }\end{array}$ & 0,0026 \\
\hline 27 & Terong & $\begin{array}{l}\text { Solanum } \\
\text { melongena L }\end{array}$ & Solanaceae & 0,0026 \\
\hline 28 & Kentang & $\begin{array}{l}\text { Solanum } \\
\text { tuberosum L. }\end{array}$ & Solanaceae & 0,0051 \\
\hline 29 & Cabai & $\begin{array}{l}\text { Capsicum } \\
\text { frustescens } \mathrm{L}\end{array}$ & Solanaceae & 0,0051 \\
\hline 30 & Mentimun & $\begin{array}{l}\text { Cucumis } \\
\text { sativum } \mathrm{L} \text {. }\end{array}$ & Curcubitaceae & 0,0026 \\
\hline 31 & $\begin{array}{l}\text { Laos/Lengk } \\
\text { uas }\end{array}$ & $\begin{array}{l}\text { Alpinia } \\
\text { galangal L. } \\
\text { Willd. }\end{array}$ & Zingiberaceae & 0,0051 \\
\hline 32 & $\begin{array}{l}\text { Kunyit/kuni } \\
\mathrm{r}\end{array}$ & $\begin{array}{l}\text { Curcuma } \\
\text { domestica } \mathrm{L}\end{array}$ & Zingiberaceae & 0,0051 \\
\hline
\end{tabular}




\begin{tabular}{|c|c|c|c|c|}
\hline 33 & Jahe & $\begin{array}{l}\text { Zingiber } \\
\text { officinale L. }\end{array}$ & Zingiberaceae & 0,0077 \\
\hline 34 & Kencur & $\begin{array}{l}\text { Kaempferia } \\
\text { galanga L. }\end{array}$ & Zingiberaceae & 0,0051 \\
\hline 35 & $\begin{array}{l}\text { Kacang } \\
\text { panjang }\end{array}$ & $\begin{array}{l}\text { Vigna } \\
\text { cylindrica L. }\end{array}$ & Papilonaceae & 0,0051 \\
\hline 36 & $\begin{array}{l}\text { Kacang } \\
\text { tanah }\end{array}$ & $\begin{array}{l}\text { Arachis } \\
\text { hypogaea L }\end{array}$ & Fabaceae & 0,0051 \\
\hline 37 & $\begin{array}{l}\text { Pisang/ged } \\
\text { hang }\end{array}$ & $\begin{array}{l}\text { Musa } \\
\text { paradisiacal } \\
\text { L. }\end{array}$ & Musaceae & 0,0051 \\
\hline 38 & Jagung & Zea mays & Poaceae & 0,0051 \\
\hline 39 & Kopi & $\begin{array}{l}\text { Coffea } \\
\text { arabica }\end{array}$ & Rubiaceae & 0,0026 \\
\hline 40 & Manggis & $\begin{array}{l}\text { Garcinia } \\
\text { mangostana }\end{array}$ & Clusiaceae & 0,0051 \\
\hline
\end{tabular}

Tanaman pangan yang dimanfaatkan suku Using Banyuwangi termasuk dalam komoditas utama adalah padi (Oryza sativa), kacang tanah (Arachis hypogaea), jagung (Zea mays), ubi jalar (Ipomoea batatas), ketela pohon (Manihot esculenta) dan kentang (Solanum tuberosum).

Pembagian kategori pemanfaatan tanaman pangan pada masyarakat suku Using Kabupaten Banyuwangi dibagi atas bahan pangan utama, bahan pangan tambahan dan bahan minuman beraroma. Bahan pangan tambahan dibedakan atas: 1) umbi-umbian; 2) sayur-sayuran; 3) buah-buahan; 4) biji-bijian dan kacang-kacangan; 5) bumbu dan aroma masakan [8].

Tabel 2. Kategori pemanfaatan dan jumlah jenis tanaman

\begin{tabular}{llc}
\hline No & $\begin{array}{c}\text { Kategori Pemanfaatan Jenis } \\
\text { Tanaman }\end{array}$ & Jumlah \\
\hline 1 & Makanan utama atau makanan & 1 \\
& pokok & \\
2 & Makanan tambahan & 3 \\
& a. Umbi-umbian & 11 \\
& b. Sayur-sayuran & 7 \\
& c. Buah-buahan & 3 \\
& d. Biji-bijian \&kacang- & 15 \\
& $\quad$ kacangan & 2 \\
\hline
\end{tabular}

Bahan pangan utama masyarakat suku Using adalah padi (Oryza sativa). Tanaman untuk memenuhi kebutuhan umbi-umbian yaitu sebesar tiga tanaman yang meliputi: Ubi jalar (Ipomoea batatas), ketela pohon (Manihot esculenta), kentang (Solanum tuberosum) (Tabel 2).

Tanaman yang dimanfaatkan sebagai sayur-mayur yaitu semanggi (Marsilea crenata), beluntas (Pluchea indica), kelor
(Moringa cleifera L), kangkung (Ipomoea aquatic), kecipir (Psopocarpus tetragonolobus L), ketela pohon (Manihot esculenta), bambu (Bambusa sp.), terong (Solanum melongena L), mentimun (Cucumis sativum), kacang panjang ( Vigna cylindrica L), katu (Sauropus androgynus).

Makanan tambahan berupa buah-buahan yaitu sebanyak tujuh tanaman yang meliputi: papaya (Carica papaya L), alpukat (Perseae americana Mill), sirsak (Annona muricata L.), nangka (Arthocarpus heterophyllus L.), mangga (Mangifera indica L), mentimun (Cucumis sativum), pisang (Musa paradisiacal L). Tanaman untuk memenuhi kebutuhan berupa biji-bijian dan kacang-kacangan sebanyak tiga tanaman. Pada penelitian ini tanaman yang digunakan untuk memenuhi kebutuhan pangan berupa biji-bijian dan kacang-kacangan meliputi ketan (Oryza glutinosa L), kacang tanah (Arachis hypogaea L), jagung (Zea mays L).

Tanaman untuk memenuhi bahan bumbu dan aroma masakan, yaitu sebanyak 15 tanaman. Hasil dari penelitian menunjukkan tanaman yang berguna sebagai bahan bumbu dan aroma masakan meliputi kelapa (Cocos nucifera L), asam jawa (Tamarindus indica L.), belimbing wuluh (Averrhoa bilimbi L), bawang merah (Allium cepa L), bawang putih (Allium sativum L.), daun salam (Syzygium polyanthum L.), pandan betawi (Dracaena angustifolia L.), pandan wangi (Pandanus amaryllfolius L.), serai (Cymbopogon citratus L), jeruk nipis (Citrus aurantifolia L), cabai (Capsicum fustescens L), laos (Alpinia galangal L. Willd.), kunyit (Curcuma domestica L.), jahe (Zingiber officinale L.), kencur (Kaempferia galanga L.). Sedangkan tanaman yang berguna untuk minuman beraroma sebanyak dua tanaman, yaitu kopi (Coffea arabica) dan jahe (Zingiber officinale L.).

Jumlah spesies dan habitus tanaman pangan di wilayah Suku Using Kabupaten Banyuwangi. Tanaman pangan yang paling banyak digunakan oleh masyarakat suku Using Banyuwangi berhabitus perdu, semak dan terna yang masing-masing berjumlah 10 tanaman. Sisanya adalah berhabitus pohon (Tabel 3). 
Tabel 3. Jumlah spesies dan persentase tanaman pangan berdasarkan habitusnya di wilayah Suku Using Kabupaten Banyuwangi

\begin{tabular}{clcc}
\hline No & Habitus & $\begin{array}{c}\text { Jumlah Spesies } \\
\text { Tanaman Pangan }\end{array}$ & $\begin{array}{c}\text { Persentase } \\
\text { Tanaman } \\
\text { Pangan }(\%)\end{array}$ \\
\hline 1 & Pohon & 9 & 26 \\
2 & Perdu & 10 & 23 \\
3 & Semak & 10 & 26 \\
4 & Terna & 10 & 26 \\
\hline
\end{tabular}

Jumlah spesies dan pembudidayaan tanaman pangan pada masyarakat Suku Using Kabupaten Banyuwangi. Suku Using Banyuwangi memanfaatkan tanaman pangan yang berasal dari luar daerah dan hasil budi daya di halaman, pekarangan, kebun maupun areal persawahan. Cara perolehan tanaman dengan cara mendatangkan dari luar daerah biasanya diperoleh dari pasar. Cara tersebut dilakukan ketika halaman, pekarangan, kebun maupun areal persawahan tidak dijumpai tanaman budidaya yang dimaksud.

Tabel 4. Jumlah spesies tanaman pangan berdasarkan sumber perolehannya di kawasan Suku Using Kabupaten Banyuwangi

\begin{tabular}{llc}
\hline No & Cara Perolehan & $\begin{array}{c}\text { Jumlah Spesies } \\
\text { Tanaman Pangan }\end{array}$ \\
\hline 1 & Hasil Budidaya & 36 \\
2 & $\begin{array}{l}\text { Mendatangkan dari } \\
\text { luar daerah (pasar) }\end{array}$ & 3 \\
\hline
\end{tabular}

Tanaman pangan yang diperoleh dari hasil budidaya sebanyak 36 jenis (Tabel 4). Tanaman yang tidak dihasilkan dari kebun, pekarangan maupun persawahan masyarakat suku Using adalah sebanyak tiga jenis, yaitu bawang merah (Allium cepa), bawang putih (Allium sativum) dan kentang (Solanum tuberosum).

Bagian tanaman pangan yang digunakan oleh masyarakat Suku Using Kabupaten Banyuwangi. Setiap tanaman pangan memiliki bagian tertentu yang dimanfaatkan sebagai bahan makanan. Bagian tanaman yang biasa dimanfaatkan sebagai bahan pangan meliputi buah, daun, bunga, umbi, rimpang, batang, dan tunas (rebung). Spesies tertentu ada yang lebih dari satu bagian tanaman dimanfaatkan sebagai bahan pangan.
Tabel 5. Bagian tanaman pangan yang dimanfaatkan oleh masyarakat Suku Using Kabupaten Banyuwangi

\begin{tabular}{llc}
\hline No & \multicolumn{1}{c}{$\begin{array}{c}\text { Bagian yang } \\
\text { Digunakan }\end{array}$} & $\begin{array}{c}\text { Jumlah Spesies } \\
\text { Tumbuhan Pangan }\end{array}$ \\
\hline 1 & Batang & 1 \\
2 & Daun & 6 \\
3 & Daun Muda & 4 \\
4 & Bunga & 1 \\
5 & Jantung (pisang) & 1 \\
6 & Buah & 16 \\
7 & Umbi & 5 \\
8 & Rimpang & 4 \\
9 & Tunas (rebung) & 1 \\
10 & Biji & 5 \\
\hline
\end{tabular}

Bagian tanaman yang paling banyak dimanfaatkan oleh masyarakat suku Using Banyuwangi adalah buah yaitu sebesar 16 jenis tanaman (Tabel 5). Bagian dari buah mengandung sumber gula, karbohidrat, vitamin, mineral dan lemak yang sangat berguna bagi makhluk hidup [9]. Bagian tanaman lain yang sering digunakan adalah daun, umbi, biji dan rimpang. Bagian tersebut juga banyak mengandung zat bermanfaat bagi makhluk hidup. Bagian tanaman yang paling sedikit dimanfaatkan sebagai sumber pangan adalah batang, bunga, jantung (pisang), dan tunas (rebung).

Cara pengolahan dan pemakaian tanaman pangan pada masyarakat Suku Using Kabupaten Banyuwangi. Proses terpenting agar bahan pangan dapat dimanfaatkan adalah cara pengolahan dan pemakaian bagian tanaman. Cara pengolahan tanaman sebagai bahan pangan oleh masyarakat suku Using Kabupaten Banyuwangi dilakukan dengan cara direbus, dimasak, tanpa pengolahan (langsung dikonsumsi), dan dihaluskan (Tabel 6).

Tabel 6. Cara Pengolahan Tanaman Pangan

\begin{tabular}{llc}
\hline No & Cara Pengolahan & $\begin{array}{c}\text { Jumlah Spesies } \\
\text { Tanaman Pangan }\end{array}$ \\
\hline 1 & Direbus & 4 \\
2 & Dimasak & 26 \\
3 & Tanpa Pengolahan & 7 \\
4 & Dihaluskan & 3 \\
\hline
\end{tabular}

Tanaman yang diolah dengan cara direbus meliputi jagung (Zea mays), kacang tanah (Arachis hypogaea), semanggi (Marcelia crenata), kelor (Morenga oleifera). Sebagian besar tanaman dikonsumsi dengan melewati 
proses pengolahan dengan cara dimasak, baik dengan cara dikukus, digoreng maupun dicampur dengan bahan rempah. Sebagian tanaman dikonsumsi dalam bentuk buahbuahan tanpa melewati proses pengolahan, diantaranya adalah buah papaya (Carica papaya), mentimun (Cucumis sativum L.), pisang (Musa paradisiacal L.), alpukat (Perseae Americana), manggis (Garcinia mangostana), mangga (Mangifera indica), sirsak (Annona muricata). Tanaman yang diolah dengan cara dihaluskan adalah bawang merah (Allium cepa L.), bawang putih (Allium sativum L.), dan cabai (Capsicum frustescens L)

Tanaman pangan fungsional, cara pemakaiannya melalui tiga cara, yaitu dimakan, dimasukkan dalam masakan, dan diminum [10]. Cara pemakaian tanaman pangan oleh masyarakat Suku Using di Kabupaten Banyuwangi diketahui turuntemurun dari generasi pendahulu. Cara pemakaian tanaman pangan oleh suku Using dikategorikan atas tiga cara yaitu dimakan, ditambahkan dalam masakan dan dijadikan minuman.

Tabel 7. Cara pemakaian tanaman pangan

\begin{tabular}{llc}
\hline No & \multicolumn{1}{c}{ Cara Pemakaian } & $\begin{array}{c}\text { Jumlah Spesies } \\
\text { Tanaman Pangan }\end{array}$ \\
\hline 1 & Dimakan & 21 \\
2 & $\begin{array}{l}\text { Ditambahkan dalam } \\
\text { masakan }\end{array}$ & 14 \\
3 & Diminum & 4 \\
\hline
\end{tabular}

Cara pemakaian tanaman pangan paling banyak adalah dijadikan makanan, yaitu sejumlah 21 tanaman (Tabel 7). Tanaman yang cara pemakaiannya dengan cara dimakan adalah dari golongan makanan pokok, sayurmayur dan buah-buahan. Tanaman tersebut memang mengandung zat yang paling dibutuhkan oleh tubuh, yaitu karbohidrat, mineral dan vitamin. Tanaman yang cara pemakaiannya dengan cara ditambahkan dalam masakan adalah tanaman yang biasa dimanfaatkan sebagai bumbu atau sebagai bahan tambahan pada masakan, yaitu sebanyak 14 jenis. Tanaman yang cara pemakaiannya dengan diminum hanya ada empat tanaman.

Deskripsi tanaman bermanfaat sebagai bahan pangan pada masyarakat Suku Using Kabupaten Banyuwangi
Semanggi (Marsilea crenata). Banyuwangi mendapatkan tanaman ini dari areal persawahan. Tanaman semanggi dimanfaatkan sebagai sayur konsumsi. Cara pengolahannya adalah dengan direbus. Hampir setiap hidangan berbau ritual selalu memanfaatkan tanaman ini.

Kelapa (Cocos nucifera L.). Masyarkat Suku Using di Kabupaten Banyuwangi memperoleh tanaman kelapa (Cocos nucifera) dari kebun dan pekarangan sekitar rumah. Masyarakat suku Using memanfaatkan Buah dari tanaman ini dsebagai pelengkap bumbu masakan.

Beluntas (Pluchea indica). Tanaman beluntas (Pluchea indica) banyak ditemukan di pekarangan sekitar rumah. Masyarakat Suku Using Kabupaten Banyuwangi memanfaatkan tanaman ini sebagai sayuran konsumsi seharihari. Cara pengolahannya dilakukan dengan direbus.

Pepaya (Carica papaya). Masyarakat Suku Using di Kabupaten Banyuwangi memperoleh tanaman pepaya ini dari hasil budidaya di halaman dan pekarangan rumah. Daun muda dan bunga tanaman dimanfaatkan sebagai sayur konsumsi, sedangkan buahnya dikonsumsi sebagai sumber vitamin A.

Kelor (Moringa oleifera L.). Tanaman kelor (Moringa oleifera L.) ini didapatkan oleh masyarakat suku Using, di halaman dan pekarangan rumah. Masyarakat Suku Using di Kabupaten Banyuwangi memanfaatkan daun dan buahnya untuk dimasak sebagai sayur konsumsi.

Sabrang (Ipomoea batatas L). Tanaman sabrang (Ipomoeae batatas L.) dibudidayakan masyarakat Suku Using Kabupaten Banyuwangi, di areal persawahan. Umbinya dimanfaatkan sebagai bahan pangan seharihari maupun sebagai hidangan saat kegiatan ritual.

Ketela Pohon (Manihot esculenta). Masyarakat Suku Using membudidayakan tanaman ini di areal persawahan maupun pekarangan sekitar rumah. Bagian umbinya dimanfaatkan sebagai bahan pangan sedangkan daunnya yang masih muda dimanfaatkan sebagai sayuran. 
Kangkung (Ipomoea aquatic L.). Masyarakat Suku Using Kabupaten Banyuwangi memperoleh tanaman kangkung (Ipomoea aquatic L.) dari areal persawahan. Masyarakat Suku Using memanfaatkan daun Tanaman kangkung (Ipomoeae aquatica L.) sebagai sayur konsumsi sehari-hari.

Kecipir (Psopocarpus tetragonolobus L). Masyarakat Suku Using di Kabupaten Banyuwangi membudidayakan tanaman ini di halaman atau pekarangan sekitar rumah. Mereka memanfaatkan buahnya sebagai sayur konsumsi.

Asam Jawa (Tamarindus indica L.). Masyarakat Suku Using di Kabupaten Banyuwangi memperoleh tanaman asam jawa (Tamarindus indica L.) di pinggir jalan dan pekarangan rumah. Mereka memanfaatkan buahnya sebagai pelengkap bumbu masakan.

Belimbing wuluh (Averrhoa bilimbi L). Masyarakat Suku Using di Kabupaten Banyuwangi mendapatkan tanaman ini di pekarangan rumah. Bagian buahnya dimanfaatkan oleh masyarakat Suku Using sebagai bumbu pelengkap masakan.

Alpukat (Perseae americana Mill). Masyarakat Suku Using di Kabupaten Banyuwangi mendapatkan tanaman alpukat (Perseae Americana Mill.) dari hasil budidaya di kebun dan pekarangan rumah. Buah dari tanaman ini dimanfaatkan oleh masyarakat suku Using untuk memenuhi kebutuhan akan buah-buahan.

Bawang Merah (Allium cepa L.). Masyarakat Suku Using tidak banyak yang membudidayakan bawang merah (Allium cepa L.), sehingga kebutuhan akan tanaman ini banyak diperoleh dengan mendatangkan dari luar daerah. Masyarakat Suku Using di Kabupaten Banyuwangi memanfaatkan umbi lapisnya sebagai bumbu hampir untuk semua jenis masakan.

Bawang Putih (Allium sativum L). Masyarakat Suku Using di Kabupaten Banyuwangi mendapatkan tanaman bawang putih (Allium sativum L.) dari pasar atau luar daerah. Tanaman ini dimanfaatkan sebagai bumbu pelengkap untuk masakan.
Sirsak (Annona muricata L.). Masyakarat Suku Using di Kabupaten Banyuwangi mendapatkan tanaman sirsak (Annona muricata L.) dari halaman dan pekarangan rumah. Bagian buahnya dimanfaatkan oleh masyarakat Suku Using untuk memenuhi kebutuhan akan buah-buahan.

Salam (Syzygium polyanthum). Masyarakat Suku Using mendapatkan tanaman salam (Syzygium polyanthum) dari hasil budidaya di halaman dan pekarangan rumah. Daun tanaman ini dimanfaatkan oleh Suku Using Banyuwangi sebagai rempah untuk bumbu masakan.

Pandan Betawi (Dracaena angustifolia L.). Masyarakat Suku Using di Kabupaten Banyuwangi memperoleh tanaman pandan betawi dari halaman dan pekarangan rumah. Mereka memanfaatkan daunnya sebagai pewarna alami untuk makanan.

Pandan Wangi (Pandanus amaryllfolius L.). Masyarakat Suku Using memperoleh tanaman pandan wangi dari halaman dan pekarangan rumah mereka. Daun dari tanaman ini dimanfaatkan sebagai pemberi aroma pada makanan dan minuman.

Serai (Cymbopogon citratus L). Masyarakat Suku Using Kabupaten Banyuwangi memperoleh tanaman serai (Cymbopogon citratum L.) dari hasil budidaya di halaman rumah. Pangkal batang dari tanaman ini dimanfaatkan sebagai bumbu masakan. Cara pemanfaatannya adalah dengan ditambahkan pada olahan makanan tertentu.

Padi (Oryza sativa L). Masyarakat Suku Using Kabupaten Banyuwangi membudidayakan tanaman padi (Oryza sativa L.) di areal persawahan. Tanaman ini dibudidayakan sebagai komuditas utama masyarakat Suku Using Banyuwangi. Bulir bijinya dimanfaatkan sebagai bahan pangan utama.

Ketan (Oryza sativa var. glutinosa). Masyarakat Suku Using Kabupaten Banyuwangi membudidayakan tanaman ketan (Oryza sativa var. glutinosa) di areal persawahan. Masyarakat Suku Using 
memanfaatkan bulir biji tanaman ini sebagai bahan pangan.

Bambu (Bambusa sp.). Masyarakat Suku Using Banyuwangi memperoleh tanaman bamboo (Bambusa sp.) dari pekarangan dan halaman rumah. Masyarakat Suku Using Banyuwangi memanfaatkan tunas muda tanaman bamboo sebagai bahan pangan. Pengolahannya adalah dengan direbus, kemudian dirajang dan dimasak bersama bumbu pelengkap.

Nangka (Arthocarpus heterophyllus L.). Masyarakat Suku Using Banyuwangi memperoleh tanaman nangka dari hasil budidaya di pekarangan rumah. Buah tanaman nangka dimanfaatkan oleh masyarakat Suku Using Banyuwangi untuk memenuhi kebutuhan buah-buahan, dengan cara dikonsumsi langsung ataupun diolah menjadi aneka minuman.

Jeruk Nipis (Citrus aurantifolia L). Masyarakat Suku Using Kabupaten Banyuwangi, banyak membudidayakan tanaman jeruk nipis (Citrus aurantifolia L.) di halaman dan pekarangan rumah.. Buah dan daun tanaman ini dimanfaatkan sebagai bumbu masakan. Buah tanaman ini seringkali dimanfaatkan juga untuk miuman.

Mangga (Mangifera indica L). Tanaman mangga (Mangifera indica L.) dibudidayakan oleh masyarakat Suku Using Banyuwangi di area pekarangan rumah. Masyarakat Suku Using memanfaatkan buah tanaman mangga untuk memenuhi kebutuhan akan buahbuahan.

Terong (Solanum melongena L). Masyarakat Suku Using Banyuwangi membudidayakan tanaman terong (Solanum melongena L.) di areal persawahan, halaman, dan pekarangan rumah. Buah dari tanaman terong dimanfaatkan sebagai sayuran konsumsi, khususnya pada hidangan khas Suku Using Banyuwangi "Sego Tempong”.

Kentang (Solanum tuberosum L.). Masyarakat Suku Using Banyuwangi tidak banyak membudidayakan tanaman kentang. Sehingga mereka biasa mendatangkan dari luar daerah atau membeli dari pasar. Umbi tanaman kentang ini dimanfaatkan oleh masyarakat Suku Using Banyuwangi sebagai bahan makanan.

Cabai (Capsicum fustescens L). Masyarakat Suku Using Kabupaten Banyuwangi biasa membudidayakan tanaman cabai di areal persawahan, halaman dan pekarangan rumah. Bagian tanaman yang dimanfaatkan adalah buahnya. Sensasi rasa pedas yang dimiliki buah cabai menyebabkan masyarakat Suku Using memanfaatkan buah cabai sebagai bumbu masak sehari-hari.

Mentimun (Cucumis sativum L.). Tanaman mentimun banyak dibudidayakan oleh masyarakat Suku Using Kabupaten Banyuwangi di areal persawahan. Buah tanaman ini dimanfaatkan sebagai buah konsumsi dan sayuran.

Lengkuas (Alpinia galangal L. Willd.). Tanaman lengkuas biasa dibudidayakan oleh masyarakat Suku Using Banyuwangi di pekarangan rumah. Tanaman ini biasa disebut sebagai "empon-empon" dan dimanfaatkan sebagai bumbu masakan.

Kunyit (Curcuma domestica L). Masyarakat Suku Using di Kabupaten Banyuwangi membudidayakan tanaman kunyit di pekarangan sekitar rumah. Rimpang tanaman kunyit ini dimanfaatkan oleh masyarakat Suku Using sebagai bumbu masakan.

Jahe (Zingiber officinale L). Masyarakat Suku Using Kabupaten Banyuwangi memperoleh tanaman jahe dari hasil budidaya di pekarangan rumah. Jahe dimanfaatkan rimpangnya oleh Suku Using sebagai bumbu masakan dan campuran untuk minuman beraroma

Kencur (Kaempria galanga L.). Tanaman kencur diperoleh masyarakat Suku Using Kabupaten Banyuwangi dari hasil budidaya di pekarangan rumah. Rimpang tanaman kencur dimanfaatkan sebagai bumbu untuk masakan.

Kacang Panjang (Vigna cylindrica L.). Masyarakat Suku Using Kabupaten Banyuwangi mendapatkan tanaman kacang panjang (Vigna cylindrica L.) dari hasil budidaya di areal persawahan. Tanaman 
tersebut dimanfaatkan sebagai bahan pangan tambahan, dalam bentuk sayur-mayur.

Kacang Tanah (Arachis hypogaea L). Masyarakat Suku Using Kabupaten Banyuwangi mendapatkan tanaman kacang panjang dari hasil budidaya di areal persawahan, ladang, atau pekarangan rumah. Tanaman ini dapat digunakan memenuhi kebutuhan pangan dalam bentuk kacangkacangan.

Pisang (Musa paradisiacal L.). Masyarakat Suku Using Banyuwangi biasa membudidayakan tanaman pisang (Musa paradisiacal L.) di pekarangan rumah. Tanaman ini dimanfaatkan buahnya oleh masyarakat suku Using untuk berbagai kepentingan, salah satunya untuk kebutuhan pangan. Buah pisang biasa dikonsumsi dengan cara dimakan langsung atau dimasak menjadi olahan pangan lainnya.

Jagung (Zea mays). Masyarakat Suku Using Kabupaten Banyuwangi menanam jagung di areal persawahan. Tanaman ini dimanfaatkan bijinya sebagai salah satu makanan pokok alternative selain padi.

Kopi (Coffea arabica). Masyarakat Suku Using Banyuwangi membudidayakan tanaman kopi (Coffea Arabica) di pekarangan ataupun kebun. Tanaman ini dimanfaatkan bijinya sebagai bahan dasar minuman beraroma.

\section{Manggis (Garcinia mangostana).} Tanaman manggis (Garcinia mangostana) banyak dibudidayakan oleh masyarakat Suku Using Kabupaten Banyuwangi. Mereka membudidayakan di pekarangan dan halaman rumah. Buah tanaman manggis dimanfaatkan oleh Suku Using Kabupaten Banyuwangi untuk memenuhi kebutuhan makanan tambahan berupa sumber buah-buahan.

\section{KESIMPULAN}

Hasil penelitian menunjukkan tanaman sebagai bahan pangan bagi masyarakat suku Using Kabupaten Banyuwangi s sebanyak 40 spesies dan tergabung dalam 25 famili. Tanaman pangan tersebut dikategorikan dalam bahan pangan utama hanya satu jenis tanaman, bahan pangan tambahan berjumlah 39 jenis dan dibedakan atas kategori umbi-umbian, sayur-mayur, buah-buahan, biji-bijian dan kacang-kacangan serta bumbu dan aroma masakan. Habitus tanaman pangan paling banyak adalah perdu, semak dan terna. Tanaman pangan banyak diperoleh dari hasil budidaya masyarakat Suku Using. Masyarakat Suku Using Banyuwangi banyak memanfaatkan organ buah dari tanaman pangan. Cara pengolahan yang paling sering dilakukan dengan dimasak.

\section{UCAPAN TERIMA KASIH}

Ucapan terima kasih disampaikan kepada tim LPPM Universitas PGRI Banyuwangi yang telah memfasilitasi penelitian ini hingga selesai. Begitu juga kepada Ristekdikti yang telah memberikan dana hibah pada Penelitian Dosen Pemula ini.

\section{DAFTAR PUSTAKA}

[1] Rahayu S (2013) Pemanfaatan tumbuhan pangan dan obat oleh masyarakat Kampung Sinarwang di Sekitar Hutan Gunung Salak, Kabupaten Bogor. Skripsi. Institut Pertanian Bogor, Bogor.

[2] Martin GJ (2004) Etnobothany a method manual. Chapman and Hall, London.

[3] Sartika W (2013) Studi etnobotani keanekaragaman pangan Etnis Batak Toba di Kecamatan Baktiraja Kabupaten Humbang Hasundutan. JUPIIS: Jurnal Pendidikan Ilmu-Ilmu Sosial 5(2): 20 25 ..

[4] Indiarti W, Mahdi A, Mulyati T (2013) Pengembangan program desa wisata dan ekowisata berbasis partisipasi masyarakat Desa Kemiren Kabupaten Banyuwangi. Laporan Penelitian Inovatif Bidang Pariwisata, Universitas PGRI Banyuwangi.

[5] BAPPEDA Kabupaten Banyuwangi www.banyuwangikab.go.id/profil/peta.h tm. Peta administrasi kabupaten banyuwangi. Diakses tanggal 30 Mei 2017.

[6] Anisfiani W, Asyiah IN, Aprilya S (2014) Etnobotani bahan kosmetik oleh masyarakat Suku Using di Kabupaten Banyuwangi sebagai bahan ajar populer. Pancaran Pendidikan 3(3): 53-62.

[7] Moeljopawiro S,.Manwan I (1992) Pengembangan dan pemanfaatan 
tanaman pangan di Indonesia. Prosiding Seminar dan Lokakarya Nasional Etnobotani, Cisarua-Bogor, DEPDIKBUDDEPTAN-LIPI

Perpustakaan Nasional RI. Diedit oleh Nasution, RE, Riswan S, Tjitropranoto $\mathrm{P}$, Waluyo EB, Martowikrido W, Roemantyo H, Wardoyo SS., hal. 288299.

[8] Nurchayati N, Ardiyansyah F (2018) Kajian etnobotani masyarakat Suku Using Kabupaten Banyuwangi. Bioma 3(2): 87-101.

[9] Apriliani A, Sukarsa S, Hidayah HA (2014) Kajian etnobotani tumbuhan sebagai bahan tambahan pangan secara tradisional oleh masyarakat di Kecamatan Pekuncen Kabupaten Banyumas. Scripta Biologica 1(1): 7684.

[10] Salsabila PP, Zuhud EAM, Siswoyo (2014) Pemanfaatan tumbuhan pangan dan obat oleh masyarakat di Dusun Palutungan Desa Cisantana Sekitar Taman Nasional Gunung Cermei. Media Konservasi 19(1): 146-153. 